\section{Callus and Cell Suspension Cultures from Dormant Stems of Peach}

\section{F. Mark Schiavone and M.E. Wisniewski \\ U.S. Department of Agriculture, Agricultural Research Service, Appalachian Fruit Research Station, 45 Wiltshire Road, Kearneysville, WV 25430-9802}

Additional index words. Prunus persica, tissue culture

Explants of peach [Prunus persica (L.) Batsch.] have been derived from buds, stems, leaves, or anthers collected during the growing season (Heuser, 1972; Stiles, 1974; Tukey, 1937; Bradley and Dahmen, 1971; Hammerschlag, 1983). Although Ochatt and Caso (1983) produced shoots from dormant buds, it appears no research has been reported on, callus production directly from dormant stem tissue. Ability to derive callus from dormant tissue would be advantageous, since it would allow callus to be obtained during the entire year.

Current season's growth from several genotypes of peach (Table 1) was collected at the Appalachian Fruit Research Station, Kearneysville, W.Va., on 6 or 30 Nov., and 2 or 6 Dec. 1988. Buds were removed and stems cut into $\approx 10-\mathrm{cm}$ lengths. This material was soaked in $95 \%$ ethanol for $5 \mathrm{~min}$ and transferred to a solution of $15 \%$ Clorox : $0.01 \%$ Triton X-100 (v/v) for 4 min. Stems were then rinsed three times in sterile distilled water and cut into $1-\mathrm{cm}-$ long segments. These were debarked and either quartered longitudinally or kept whole. Xylem and bark strips were cultured separately on either a Murashige and Skoog (MS) medium (Murashige and Skoog, 1962) containing $3 \%$ sucrose, $0.5 \mu \mathrm{M} \mathrm{IBA}$, and 5,10 , or $50 \mu \mathrm{m}$ 2,4-D, or Woody Plant Medium WPM) (Lloyd and McCown, 1981) containing sucrose, $0.5 \mu \mathrm{M} \mathrm{IBA}$, and $5 \mu \mathrm{m} 2,4-\mathrm{D}$ (Sigma, St. Louis). Both media contained $1.2 \%$ agar $(\mathrm{w} / \mathrm{v})$ and the $\mathrm{pH}$ of each was adjusted to 5.8 before autoclaving. Cultures were maintained in the dark at $21 \mathrm{C}$ for 6 to 8 weeks.

No callus grew from bark strips. In contrast, substantial growth was observed on both whole and quartered stems within 2 weeks ber were sometimes contaminated by Cytospora spp., whereas all tissue collected in December was not. All genotypes produced callus on each medium, although the greatest amount occurred at 1 or $5 \mu \mathrm{m}$ 2,4-D (data not shown).

To induce suspension cells, $1-\mathrm{cm}^{3}$ blocks

Received for publication 12 June 1989. The cost of publishing this paper was defrayed in part by the payment of page charges. Under postal regulations, this paper therefore must be hereby marked advertisement solely to indicate this fact. (Fig. $1 \mathrm{~A}$ and B). Explants taken in Novem- of callus were trimmed from larger pieces and individually immersed in a single well of a six-well culture dish containing $3 \mathrm{ml}$ of liquid MS medium (without IBA) per well. Either the 2,4-D or the BAP concentration was varied. Two replicate wells/treatment for each genotype were used. This procedure maintained a high cell : volume ratio.

Plates were incubated in the dark at $21 \mathrm{C}$ for 24 days on a rotary shaker at $100 \mathrm{rpm}$. Subsequently, 0.1-ml samples were drawn from the wells and the number of single cells and clumped cells recorded. The most successful hormone treatments are presented in Table 1. The greatest success in obtaining suspension cells was achieved in 'Sunhigh', which produced a soft, paste-like callus on both solidified MS and WPM. The secondmost prolific suspension cell producer was KV862478; [(Empress dwarf OP) OP] $\times$ PI 442380. Callus obtained from this selection was hard and appeared resistant to sloughing cells. Therefore, physical appearance of callus was not associated with the ability to produce suspension cells. In all genotypes, suspension cells appeared as an even mixture of single cells, clusters of two to five cells, and larger clusters up to an estimated 100 cells/cluster. Morphologically, cells were evenly distributed between elongated, highly vacuolated cells and smaller, isodiametric cells with dense cytoplasm (Fig. 1C). After 4
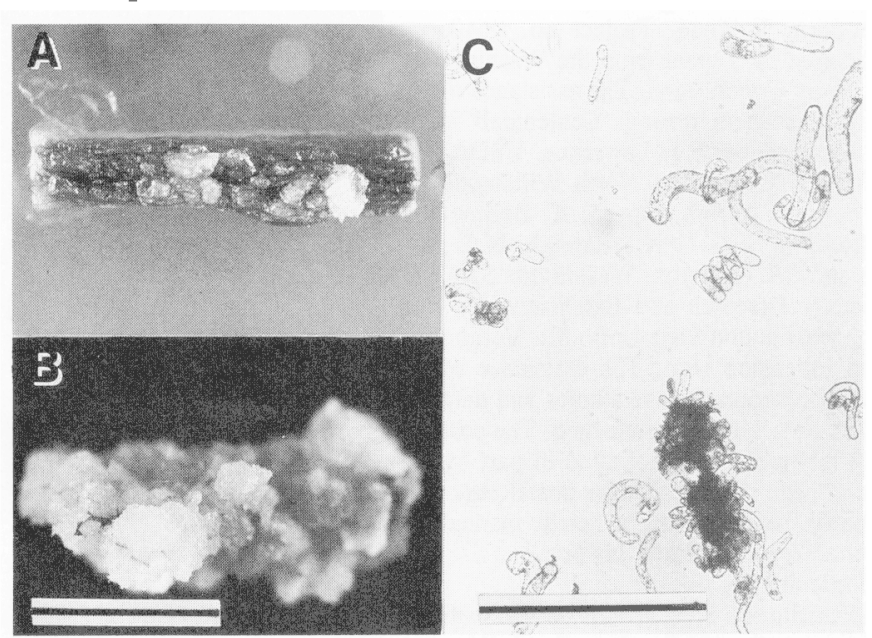

Fig. 1. Callus and suspension cell cultures derived from dormant stem tissue of peach. (A) Effect of $50 \mu \mathrm{M}$ and (B) $5 \mu \mathrm{M} 2,4-\mathrm{D}$ in MS medium on callus production in 'Bailcy'. Bar $=0.5 \mathrm{~cm}$. (C) Suspension cells derived from callus of 'Sunhigh'. Bar $=500 \mu \mathrm{m}$.

${ }^{y}$ See test for parentage.

months in culture, stationary-phase cultures maintained cell densities similar to those given in Table 1.

\section{Literature Cited}

Bradley, M.V. and W.J. Dahmen. 1971. Cytohistological effects of ethylene, 2,4-D, kinetin and carbon dioxide or peach mesocarp callus

Hammerschlag, F.A. 1983. Factors influencing the frequency of callus formation among cultured peach anthers. HortScience 18:210-211.

Heuser, C.W. 1972. Response of callus cultures of Prunus persica, P. tomentosa, and P. besseyi to cyanide. Can. J. Bot. 50:2149-2152.

Lloyd, G. and B. McCown. 1981. Commerciallyfeasible micropropagation of mountain laurel, Kalmia latifolia, by use of shoot tip culture. Comb. Proc. Intl. Plant Prop. Soc. 30:421-427.

Murashige, T. and F. Skoog. 1962. A revised medium for rapid growth and bioassays with tobacco tissue cultures. Physiol. Plant. 15:473497.

Ochatt, S.J. and O.H. Case. 1983. Dormant meristem-tips as a source for producing Red-leaf peach [Prunus persica $(\mathrm{L}$.$) Batsch.] shoots in$ vitro. Phyton 43:21-28.

Stiles, H.D. 1974. Tissue and organ culture of haploid and diploid peaches. PhD Diss., Univ.

Tukey, H.B. 1937. Plant parts of deciduous fruits which give evidence of being favorable for tissue culture. Proc. Natl. Acad. Sci. 23:557-580.
Table 1. Optimal concentrations of growth regulators for production of suspension cells in five genotypes of peach.

\begin{tabular}{lccc}
\hline \hline & \multicolumn{2}{c}{$\begin{array}{c}\text { Growth } \\
\text { regulator } \\
\text { concn }(\mu \mathrm{M})\end{array}$} & \\
\cline { 2 - 4 } Genotype & $2,4-\mathrm{D}$ & BAP & Cells/ml $\mathrm{m}^{\mathrm{n}}$ \\
\hline Sunhigh & 1.0 & 5.0 & $289,900 \pm 7,150$ \\
KV862478y & 1.0 & 5.0 & $46,310 \pm 2,530$ \\
Bailey & 5.0 & 0.5 & $7,410 \pm 240$ \\
Boone & & & \\
$\quad$ County & 0.5 & 1.0 & $1,530 \pm 57$ \\
Reliance & 0.5 & 0.5 & $160 \pm 15$
\end{tabular}

${ }^{2}$ Mean of three counts/well $\pm 1 \mathrm{SD}$. cultured in vitro. Phytomorphology 21:154-164. of Florida, Gainesville.

HortScIEnCE, Vol. 25(4), AprIL 1990 